\title{
Er en politisk skandale en politisk skandale? \\ danske medierede politiske skandaler i et komparativt perspektiv
}

Arjen van Dalen adjunkt, ph.d., Center for Journalistik ved Institut for Statskundskab, Syddansk Universitet.

Morten Skovsgaard adjunkt, ph.d., Center for Journalistik ved Institut for Statskundskab, Syddansk Universitet.

Til trods for at medieforskere, journalister og politikere i forskellige mediesystemer er enige om, at massemedierne har magten til at fremme eller sætte en stopper for en politikers karriere, varierer typerne af skandaler, som dækkes i forskellige lande. Denne artikel analyserer det særlige ved de danske medierede skandaler ved at sammenligne dem med dækningen af skandaler i Storbritannien, Spanien og Tyskland. Baseret på en spørgeskemaundersøgelse blandt politiske journalister i fire lande præsenterer artiklen først forskellene i den journalistiske kultur mellem de fire lande ved at undersøge journalisternes rolleopfattelser. Vi argumenterer for, at forskellige rolleopfattelser (vagthund, underholder eller politisk part) alle kan føre til dækningen af politiske skandaler, men at typen af skandaler varierer på tværs af de forskellige lande på dimensionerne regelbrud-normbrud og offentligt liv-privatliv. Den danske dækning af politiske skandaler ligger tættest på den tyske dækning med vægt på vagthundsrollen, ingen synlig partiskhed (som der er i Spanien) og en modvillighed mod at dække politikernes sexliv eller anvende etisk diskutable journalistiske metoder (som det sker i Storbritannien). Når en historie om en politikers privatliv bliver dækket bredt i de danske medier, er det som regel, fordi politikeren har brudt normer i deres private liv, som de enten selv prædiker i deres offentlige virke, eller som fremstår som særligt vigtige i deres offentlige virke.
„Når jeg ser min familie belejret af pressen, og BT nærmest overvåger vores hus og holder øje med, hvornår vi kommer og går - og i et par tilfælde også tiltaler vores børn, så står jeg helt af. Det er ikke noget liv“. Henriette Kjær. ${ }^{1}$

Eksemplet viser, at mediernes dækning er så magtfuld, at den kan føre til politikeres storhed og fald. Især i de senere år har medierne dækket politiske skandaler mere massivt (se Ørsten i dette nummer). Ikke bare i Danmark er journalister og politikere enige om, at medierne har magt til både at fremme og sætte en stopper for en politikers karriere (Van Aelst et al. 2008; Van Dalen og Van Aelst under udgivelse).

Men selvom skandaler er en central del af den politiske journalistik over det meste af verden, varierer typen af skandaler i medierne på tværs af lande (Tumber og Waisbord 2004; Esser og Hartung 2004; Holtz-Bacha 2004; Canel og Sanders 2006). Vi har dog temmelig begrænset viden om dækningen af danske politiske skandaler, og især hvordan den ser ud i sammenligning med andre landes. Ved at identificere ligheder og forskelle i dækningen af politiske skandaler i lande fra andre mediesystemer kan vi få en bedre forståelse af, hvad der er de typiske træk ved den danske dækning af politiske skandaler, og hvorfor dækningen ser ud, som den gør. 
Derfor analyserer denne artikel sammenhængen mellem nationale forskelle i journalistiske kulturer og nationale forskelle i dækningen af politiske skandaler (Hanitzsch 2007). Artiklen argumenterer for, at den danske journalistiske kultur er forskellig fra den journalistiske kultur i andre europæiske lande, og at det har indflydelse på, hvilke politiske skandaler der dækkes i Danmark.

Vi beskriver de karakteristiske træk ved de danske politiske skandaler ved at sammenligne dem med politiske skandaler i Storbritannien, Spanien og Tyskland. De tre lande er valgt som repræsentanter for hvert sit mediesystem (Hallin og Mancini 2004; Donsbach og Patterson 2004). Storbritannien tilhører det liberale mediesystem, ligesom USA, Irland og Canada. Det er karakteriseret ved en lav grad af intervention fra staten, en ikke-institutionaliseret selvregulering af pressen (Hallin og Mancini 2004) og et stærkt konkurrencepræget og kommercialiseret mediemarked (Strömbäck og Shehata 2007). Som andre middelhavslande, såsom Frankrig, Portugal og Grækenland, tilhører Spanien det polariserede-pluralistiske mediesystem. Det er karakteriseret ved en sen udvikling af pressen, en tradition for statsintervention på mediemarkedet, tætte bånd mellem bestemte partier/politikere og bestemte medier (politisk parallelisme) samt en stærk kontrol med medierne fra udefrakommende aktører, hvilket hæmmer udviklingen af en professional kultur blandt journalisterne. Den tredje model er den demokratisk-korporatisktiske, som er karakteriseret af en tidlig udvikling af pressen, institutionaliseret selvregulering og en stærkt udviklet professionel identitet blandt journalsiterne. Både Tyskland og Danmark, men også eksempelvis Norge, Sverige og Holland, hører til denne model (Hallin og Mancini 2004).

Med udgangspunkt i et komparativt perspektiv arbejder denne artikel altså ud fra følgende spørgsmål2:

Hvad karakteriserer de danske medierede, politiske skandaler $i$ sammenligning med medierede, politiske skandaler i Spanien, Storbritannien og Tyskland? Hvordan hanger det sammen med forskelle $i$ den journalistiske kultur på tvers af landene?

Artiklen vil besvare spørgsmålene ved først at definere medierede, politiske skandaler. Derefter præsenteres en typologi over de medierede, politiske skandaler, hvor der skelnes mellem to dimensioner. For det første skelner vi mellem brud på normer, der ikke er forankret i decideret lovgivning, og brud på formelle regler og lovgivning. For det andet skelner vi mellem politikerens private liv og hans eller hendes offentlige rolle.

Baseret på en spørgeskemaundersøgelse præsenterer vi forskellene i den journalistiske kultur mellem de fire lande via journalistiske rolleopfattelser og viser, at forskellige rolleopfattelser, som vagthund, underholder el- ler politisk aktør, alle kan føre til dækning af politiske skandaler, men at typen af skandaler, som følger heraf, varierer på tværs af de forskellige lande på dimensionerne regelbrud-normbrud og offentligt liv-privatliv. Til sidst ser vi på, hvordan Danmark adskiller sig fra de øvrige lande i forhold til journalistiske kulturer og dækningen af politiske skandaler

\section{Medierede politiske skandaler: en definition og en typologi}

Thompson $(1997 ;$ 2002) peger på fem træk, der adskiller skandaler fra ikke-skandaler. Disse træk kan også ses som skridt i udviklingen af en skandale. For det første må nogen bryde en social norm. For det andet indebærer en skandale et element af hemmeligholdelse eller fortielse, men andre end de direkte involverede har kendskab til eller stærk formodning om deres eksistens. For det tredje skal disse ikke-deltagere tage afstand fra handlingen og se den som moralsk forkert. For det fjerde skal denne misbilligelse ikke bare være privat, men skal udtrykkes offentligt. Og for det femte risikerer udøveren af handlingen at skade sit offentlige ry og rygte på baggrund af handlingen (Thompson, 1997; 2002).

Massemedierne spiller en central rolle i at bestemme, om handlinger i den grå zone mellem tydeligvis korrekt og tydeligvis forkert fører til skandaler, da de oftest er involveret i flere af de fem skridt, som ifølge Thompson (1997) definerer skandaler. Journalister kan opdage og offentliggøre en overtrædelse af normer eller regler, så borgere, der ikke er involveret, læser eller hører om den. Det kan få folk til at tage stilling til handlingen, og medierne kan også selv skrive fordømmende ledere eller give plads til opfølgende historier, hvor aktører fordømmer handlingen. Medierne kan omvendt beslutte, at historien ikke skal dækkes yderligere, eller de kan tone betydningen af skandalen ned (Lull og Hinerman 1997, 13). Da medierne på den måde ofte både kan sætte en skandale i gang, forme den og afslutte den, er de fleste skandaler medierede.

Der er flere forskellige typer af medierede politiske skandaler. Nogle skandaler opstår, når politikere overtræder formelle regler forankret i lovgivning, mens andre skandaler opstår, når politikere træder ved siden af normer, som er en del af samfundsmoralen, men ikke nedfældet i i formel lovgivning. Der er også en forskel mellem, om det er i sit private liv eller om det er i sit offentlige virke, at en politiker træder på den landmine, der udløser en medieret politisk skandale. Når vi kombinerer dimensionen overtrædelse af formel lovgivningovertrædelse af normer med dimensionen privat-offentlig virke, kan skandalerne placeres i fire kategorier: Skandaler, der skyldes en overtrædelse af normer for politikerens 
Figur 1: Typologi over medierede skandaler

\begin{tabular}{|l|l|l|}
\hline & Regelbrud/brud på lovgivning & Normbrud \\
\hline Det offentlige liv & $\begin{array}{l}\text { Brud på regler forankret i lovginning i det offentige virke } \\
\text { som politiker }\end{array}$ & Brud på normer i det offentige virke som politiker \\
\hline Privatlivet & $\begin{array}{l}\text { Brud på regler forankret i lovginning som privatperson } \\
\text { uden forbindelse til det offentlige virke som politiker }\end{array}$ & $\begin{array}{l}\text { Brud på normer eller samfundsmoral som privatperson } \\
\text { uden forbindelse til det offentlige virke som politiker }\end{array}$ \\
\hline
\end{tabular}

offentlige rolle, skandaler, der skyldes en overtrædelse af lovgivning knyttet til politikerens offentlige rolle, skandaler, der skyldes overtrædelser af normer i privatlivet og skandaler, der skyldes overtrædelser af lovgivning i privatlivet (figur 1).

Denne typologi kan hjælpe os med at afdække, hvordan typen af skandaler varierer, samt identificere ligheder og forskelle i dækningen af de danske politiske skandaler i forhold til dækningen af politiske skandaler i Spanien, Storbritannien og Tyskland.

\section{Skandaler og journalistiske kulturer}

Forskere i forskellige lande har peget på særlige træk ved den journalistiske kultur som årsag til, at særlige typer af politiske skandaler dækkes (Canel og Sanders 2006, 196 ff., Esser og Hartung 2004, 1065, Holz-Bacha 2004). Den centrale tese i denne artikel er, at den journalistiske kultur varierer på tværs af lande, og at dette vil føre til, at medierne dækker forskellige typer politiske skandaler (Tumber og Waisbord 2004).

Som beskrevet ovenfor spiller massemedierne en central rolle i forhold til de politiske skandaler. Mens individuelle medier selvstændigt kan beslutte at køre en skandalehistorie, har den journalistiske kultur stor indflydelse på, om en skandalehistorie bragt i et medie bliver fulgt bredt op i de øvrige medier og på den måde forstærket, ved at nye aspekter drages frem og mulige konsekvenser diskuteres. Selvom enkelte medier (ofte tabloidaviser) ikke altid holder sig til de traditionelle normer for, hvornår noget kan betegnes som en politisk skandale, bliver disse historier ikke altid fulgt op i mainstreammedierne, og ikke sjældent bliver tabloidaviserne tværtimod fordømt for at gå for langt i forhold til de fremherskende normer i den journalistiske kultur.

Den journalistiske kultur kan defineres som „et særligt sæt ideer og praksisser, hvorigennem journalister bevidst eller ubevidst legitimerer deres rolle i samfundet og gør deres arbejde meningsfyldt for både dem selv og andre" (Hanitzsch 2007, 369). Deuze (2002) beskriver journalistiske kulturer som journalisters verdenssyn og deres normative forståelse af deres rolle i samfundet. De normative ideer kommer til udtryk i rolleopfattelser som i stor udstrækning deles af journalister i et land. Journalister baserer deres rolleopfattelse på „forventninger, som journalister mener, eksisterer i samfundet og blandt forskellige interessenter, som de opfatter som normativt acceptable“ (Donsbach 2008, 1).

Rolleopfattelser har været studeret på en lang række dimensioner (se Vos 2009 for et overblik), men når det kommer til komparative studier af journalistiske kulturer „differentierer de eksisterende teoretiske modeller tre dimensioner, som alle forbundet med hinanden" (Donsbach 2008, 1). Den første dimension gælder ideen om, at journalister spiller en aktiv rolle i den politiske proces og fungerer som en vagthund eller fjerde statsmagt. Den anden dimension vedrører, om journalisterne fungerer som politiske aktører ved at vælge side i den politiske proces. Den tredje dimension går på den vægt, journalister lægger på at underholde og nå et så bredt publikum som muligt.

Empiriske undersøgelser har endvidere vist, at det reelt er de tre relevante dimensioner for forskelle i journalistiske kulturer på tværs af lande i forskellige mediesystemer (Van Dalen og Van Aelst under udgivelse; Donsbach og Patterson 2004). Samtidig har tidligere undersøgelser af baggrunden for dækningen af skandaler vist, at disse forskellige rolleopfattelser alle kan føre til journalistisk dækning af skandaler. Det er vores tese, at typen af skandaler, som bliver dækket, er forskellig, alt efter hvilke rolleopfattelser der dominerer den nationale journalistiske kultur.

Journalister, der opfatter sig selv som samfundets vagthunde, har en interesse $i$ at dække politikernes tvivlsomme handlinger, enten for at holde dem ansvarlige for handlingerne eller for at stimulere den offentlige debat om, hvorvidt sådanne handlinger er ønskelige (Lull og Hinerman 1997; Sanders og Canel 2006; Thompson 1997; Skovsgaard et al. under udgivelse). Den type journalistik er knyttet til den amerikanske Watergate-skandale, som blev afsløret af Woodward og Bernstein i 1972, og som er blevet „et definerende emblem for pressens vitale rolle i demokratiet" (Schudson 2004, 1234). Vagthunden vil oftest bide sig fast i skandaler, hvor politikere begår enten deciderede regelbrud eller bryder væsentlige 
normer i deres offentlige virke, mens politikernes privatliv i udgangspunktet er uinteressant, medmindre det har en klar indflydelse på politikerens offentlige virke.

Medier, som indtager et klart politisk standpunkt, kan forfølge deres egne politiske mål ved at afsløre skandaler, som sætter politikere eller politiske partier fra den anden side af det politiske spektrum i dårligt lys. På den ene side kan mediet stærkt fordømme handlingerne fra en politisk modstander i ledere eller kommentarer og dække sagen intensivt med god plads til kritikere, mens det på den anden side kan nedtone en politisk skandale for en allieret politiker ved mindre dækning eller forsvarstaler i ledere og kommentarer. Også her kan man forvente en primær fokus på politikerens offentlige liv, da det er vigtigst i en politisk kontekst.

For det tredje kan medierne have en mindre idealistisk grund til at dække politiske skandaler, nemlig en finansiel grund. Skandaler er levende, dramatiske og appellerende og kan på den måde tiltrække læsere, lyttere og seere, da de involverer folk i magtfulde positioner (Canel og Sanders 2006, 44). Samtidig bliver det at afsløre en skandale eller følge intensivt op på den en måde for det enkelte medie at 'brande' sig på i konkurrencen med andre medier. I litteraturen er skandaler, der fokuserer på privatlivet, blevet forklaret via værdier, der knytter sig til underholdning og en tabloid stil (Tumber 2004, 1124). Det kan knytte sig til, at politikere som privatpersoner bryder lovgivningen, men vil ofte knytte sig til overtrædelse af samfundsnormer som ved sexskandaler og utroskab.

\section{Et kig på udlandet}

For at vise sammenhængen mellem de tre dimensioner af den journalistiske kultur (vagthund, partiskhed og underholdning) og typen af skandaler, der dxkkes, beskriver vi de journalistiske kulturer i Storbritannien, Spanien og Tyskland og ser, hvordan de relaterer sig til de politiske skandaler, som dækkes i de tre lande. Efterfølgende inkluderer vi Danmark i sammenligningen for at få nye indsigter i det særlige ved den danske dækning af politiske skandaler.
De journalistiske kulturer i de fire lande er beskrevet ved hjælp af en spørgeskemaundersøgelse, der er foretaget blandt de politiske journalister i alle fire lande i 2008 (svarprocenten varierer mellem 31 i Storbritannien og 74 i Danmark (Van Dalen et al. 2011). Disse resultater relateres til et overblik over typerne af politiske skandaler, der dækkes i de forskellige lande, og til sidst diskuteres ligheder og forskelle i både den journalistiske kultur og typen af politiske skandaler med særligt fokus på Danmark.

\section{Storbritannien: Vagthund, underholdning og sek- suelle udskejelser}

Det britiske mediemarked er voldsomt konkurrencepræget $\mathrm{i}$ kraft af en høj andel af løssalg og en lang tradition for tabloidaviser med store markedsandele. Storbritannien tilhører det liberale mediesystem, hvor mediemarkedet i høj grad er kommercialiseret (dog med BBC som en stærk statsfinansieret public service-aktør), og hvor der tidligt opstod en høj grad af professionalisering blandt journalisterne (Hallin \& Mancini, 2004).

Disse kendetegn afspejler sig i den journalistiske kultur blandt de politiske journalister i Storbritannien. Mens de stort set afviser, at det skulle være vigtigt at agere talerør for bestemte grupper i samfundet, tillægger de rollen som samfundets vagthund temmelig stor betydning („At undersøge regeringens udtalelser“ og „At følge den økonomiske og politiske udvikling på en skeptisk og kritisk måde"). Det kommercielle mediemarked afspejler sig dog også i den journalistiske kultur, hvor de britiske journalister finder underholdningsrollen langt mere vigtig end deres kolleger i andre lande. Næsten halvdelen af de britiske politiske journalister svarer at det er vigtigt eller meget vigtigt at levere underholdning og afslapning, mens andelen ikke overstiger en fjerdedel i nogen af de øvrige tre lande i vores sammenligning. Samtidig lægger briterne sammenlignet med deres kolleger $i$ andre lande også mest vægt på at give folk et indblik i politikernes privatliv.

Kombinationen af det konkurrenceprægede mediemarked, vægten på vagthundsrollen og villigheden til at underholde betyder, at de politiske skandaler er meget

Tabel 1: Hvor vigtige er følgende motiver for dig, når du rapporterer om national politik? (\%, der siger vigtigt eller meget vigtigt)

\begin{tabular}{lcccc}
\hline & Storbritannien & Spanien & Tyskland & Danmark \\
\hline At undersøge regeringens udtalelser & 89 & 76 & 98 & 94 \\
At følge den økonomiske og politiske udvikling på en skeptisk og kritisk måde & 74 & 59 & 96 & 94 \\
At levere underholdning og afslapning & 48 & 20 & 23 & 18 \\
At være talerør for bestemte grupper i samfundet & 13 & 19 & 16 & 8 \\
At give folk et indblik i politikernes privatliv & 15 & 3 & 1 & 11 \\
N (minimum) & 86 & 64 & 198 & 71 \\
\hline
\end{tabular}

Kilde: En spørgeskemaundersøgelse blandt politiske journalister I fire europæiske lande (for detaljer se Van Dalen et al., 2011). 
synlige i de britiske medier (Tumber 2004; Lloyd 2004). I 2009 brød en kæmpeskandale løs i de britiske medier. Det blev afsløret, at britiske parlamentsmedlemmer i årevis havde misbrugt deres offentlige position til imod reglerne at få dækket en række private udgifter. Skandalen involverede en lang række politikere, der i større eller mindre grad havde snydt. Denne skandaletype hører til i kategorien brud på loven i den offentlige position, og at afsløre denne type skandale passer som hånd $\mathrm{i}$ handske til journalisternes vagthundsideal. En anden skandale, som Sanders og Canel (2006) peger på, er Arms to Iraqskandalen, hvor Forsvarsministeriet var under anklage for at skjule regeringens rolle i private virksomheders salg af våben til Irak. Skandaler af denne art, der omhandler magtmisbrug, er ligeledes i overensstemmelse med vagthundsidealet.

En tredje type skandale, som Canel og Sanders (2006:28) finder i Storbritannien, handler om seksuelle udskejelser som utroskab, børn uden for ægteskab og unormal seksuel adfærd. Disse skandaler hører som hovedregel til i kategorien brud på normer i den private sfære og kan knyttes til kulturen blandt de britiske politiske journalister, som finder det vigtigere end deres kolleger $i$ andre lande at levere underholdning og afslapning, samt at give indsigt i politikernes privatliv.

Et andet særligt træk ved britisk journalistik er, at de britiske journalister er mere tilbøjelige til at anvende kontroversielle journalistiske metoder som at betale for informationer, gå undercover og udgive sig for at være en anden eller få andre til fordækt at samle informationer (Weaver 1998; Sanders og Canel 2006). Hvis øvrige journalistiske principper ellers overholdes, bliver sådanne metoder generelt accepteret, når formålet er at afsløre en sandhed, som ellers ikke ville kunne rapporteres (Canel og Sanders 2006, 196).

\section{Spanien: Partiske medier og en skillelinje mellem det offentlige og det private liv}

I Spanien hersker der en noget anderledes journalistisk kultur end i Storbritannien, hvilket også viser sig i den type politiske skandaler, som dækkes i den spanske presse. Spanien tilhører, hvad Hallin og Mancini (2004) betegner som det polariserede pluralistiske mediesystem, som blandt andet er kendetegnet ved, at journalistikken er mere partisk og mindre professionaliseret end i de andre mediesystemer. Spanien har en meget kortere demokratisk tradition end Storbritannien, og medierne er stadig mindre autonome end de britiske. Især har de elektroniske public service-medier traditionelt tætte bånd til regeringen (Diez-Nicolas og Semetko 1995). Det viser sig også tydeligt i de journalistiske rolleopfattelser, hvor vagthundsrollen har markant mindre vægt end i de andre lande, samtidig med at en større andel af journalisterne mener, at det er vigtigt at være talerør for bestemte grupper i samfundet, selvom forskellene mellem landene på dette punkt er temmelig små. I sammenligning med deres britiske kolleger finder de spanske politiske journalister det ikke særligt vigtigt at give deres læsere og seere et indblik i politikernes privatliv, og kun hver femte finder det vigtigt at levere underholdning og afslapning (tabel 1). Det kan altså godt være, at de spanske journalister hælder mindre mod et vagthundsideal end deres kolleger i andre lande, men det betyder ikke, at de erstatter det med et ideal om underholdning og svælgen i politikeres privatliv.

Der er i de spanske medier en klar skillelinje mellem politikernes offentlige og private liv, som kun lejlighedsvis krydses i tv-programmer, hvor en journalistisk tabloidstil dominerer. Politikernes privatliv bliver - i modsætning til i Storbritannien - kun dækket, når politikerne vælger at præsentere dem selv som privatpersoner, eller hvis de gør sig skyldige i deciderede lovbrud. Som den journalistiske kultur lægger op til, er skandaler om politikernes sexliv fuldstændigt fraværende fra de politiske nyheder i Spanien, hvilket også understøttes af, at der ikke findes tabloidaviser på det spanske marked (Sanders og Canel 2006).

Dækningen af politiske skandaler i Spanien har i stedet mest fokuseret på konflikter mellem politiske og forretningsmæssige interesser eller sager om korruption, såsom ulovlig finansiering af partier eller ulovlig berigelse (Canel og Sanders 2006, 30-31). Bølgen af afsløringer af skandaler i begyndelsen af 1990'erne i avisen El mundo, der involverede den socialistiske regering, blev set som et tegn på, at en ny type undersøgende vagthundsjournalistik voksede frem i Spanien (Jimenez 2004). Men motiverne bag denne afdækning af skandaler bundede ikke udelukkende i ønsket om at optræde som vagthund, men var også et udtryk for politisk partiskhed. Politiske og finansielle støtter samt venskabet mellem direktøren og lederen af oppositionspartiet Partido Popular havde indflydelse på avisens redaktionelle linje, der rettede en overvældende opmærksomhed mod sager, der svækkede legitimiteten af det socialistiske regeringsparti PSOE (Pujas 2002, 161). Dermed kan afsløringerne tolkes i retning af, at journalisterne i lige så høj grad agerede talerør for bestemte grupper, som at de forfulgte et ideal om at være uafhængige og kritiske vagthunde.

Uanset om motivationen er at agere kritisk og uafhængigt eller at agere partisk, handler afsløringerne dog primært om politikernes ageren i deres offentlige rolle, og i det omfang politikernes privatliv overhovedet dækkes, er det, hvis de eksempelvis gør sig skyldige i økonomisk kriminalitet og altså bryder lovgivningen. De medierede skandaler i Spanien befinder sig altså primært i kategorierne lovbrud eller normbrud i den offentlige sfære, mens 
politikernes normbrud som privatpersoner ikke - som de gør i Storbritannien - ender som medierede politiske skandaler.

\section{Tyskland: Vagthundenes tilgang til privatlivet un- der forandring}

Nøjagtig som Danmark tilhører Tyskland det mediesystem, som Hallin og Mancini (2004) kalder det demokratiske korporative. Dette mediesystem er karakteriseret ved en stærk public service rolle for medierne og en selvreguleret presse med stor autonomi. Denne public service orientering er reflekteret i de tyske politiske journalisters rolleopfattelser, hvor de i meget høj grad støtter en vagthundsrolle (tabel 1). Et særligt træk ved det tyske mediemarked er, at der er en række magasiner, som eksempelvis Der Spiegel, der har afsløret adskillige politiske skandaler gennem tiden, og som i tråd med det fremherskende vagthundsideal har slået sig op på kritisk og grundigt at undersøge magthaverne og afsløre uregelmæssigheder. Den tyske presse har holdt politikere ansvarlige i skandaler om brud på lovgivningen såsom ulovlige partibidrag, politisk korruption eller magtmisbrug. Derudover findes der også normbrud ved skandaler, der er relateret til den specifikke tyske historie, hvilket kan være både forbindelser til nazisttiden eller forbindelser til DDR-styret i Østtyskland (Esser og Hartung 2004). Disse skandaler relaterer sig altså til politikernes offentlige rolle og inkluderer både lovovertrædelser og normbrud.

Ligesom i Spanien ser de tyske journalister det ikke som en vigtig del af deres arbejde at sætte fokus på politikernes privatliv (tabel 1). Strengt private emner som eksempelvis utroskab eller seksuelle præferencer bliver stadig betragtet som politisk tabu, selvom der har været en stigning $i$ antallet af sager, hvor man har set ,politikere trække sig tilbage på baggrund af forholdsvis små normovertrædelser i grænsefladen, hvor det private og offentlige mødes," (Esser og Hartung 2004, 1066). HoltzBacha (2004) har også påvist en stigning $i$ antallet af historier om politikeres privatliv i de tyske medier. Det kan ses som et resultat af flere forskellige udviklinger, som for eksempel kommercialisering og en ændring i den professionelle kommunikation fra politikere til journalister, hvor politikerne anvender deres privatliv som en del af en politisk strategi. Trods denne stigning er skandaler, der berører politikernes privatliv stadig et omstridt træk ved den tyske nyhedskultur. Når en sådan skandale opstår, bliver mediernes rolle stadig debatteret heftigt (HoltzBacha 2004, 50). Den journalistiske kultur med lav vægt på politikernes privatliv, gør altså, at disse skandaler stadig er omstridte, når de bliver bragt frem af medierne, og at fokus stadig er på politikernes offentlige rolle.

\section{Danske politiske skandaler}

Sammenligningen af Storbritannien, Spanien og Tyskland viser, at den journalistiske kultur og typen af medierede politiske skandaler varierer på tværs af lande. For bedre at forstå den danske dækning af politiske skandaler vil vi inddrage Danmark i sammenligningen. I analysen af de politiske skandaler trækker vi på Ørstens samlede overblik over de medierede politiske skandaler i Danmark i perioden 1980-2010 (Ørsten i dette nummer). Ligesom ved gennemgangen af Storbritannien, Spanien og Tyskland ovenfor baserer vi os ikke på en systematisk indholdsanalyse af mediedækningen, men kategoriserer skandalerne ud fra sagens substans. ${ }^{3}$

Når man ser på rolleopfattelserne, har de danske politiske journalister en særlig profil i forhold til de politiske journalister i Storbritannien, Spanien og Tyskland (tabel 1). De danske journalister lægger som deres tyske kolleger stor vægt på vagthundsrollen, men når det kommer til at være opmærksomme på politikernes privatliv, er de danske journalister mere sammenlignelige med de britiske. Danske politiske journalister lægger mindre vægt på at „være talerør for bestemte grupper i samfundet“, hvilket indikerer, at uafhængighed er særligt vigtigt for dem.

\section{Det offentlige liv}

De danske journalisters stærke selvopfattelse som samfundets vagthunde og deres trang til uafhængighed afspejler sig i de politiske skandaler, som omhandler politikernes virke som offentlige personer (se tabel 2 for et overblik). Nogle af de skandaler, som har fået størst opmærksomhed, er blevet udløst, når ministerier med en ansvarlig minister i spidsen ikke har administreret efter de fastsatte regler, hvilket altså er en overtrædelse af gældende regler og lovgivning i politikerens offentlige rolle.

Det er sket en række gange i løbet af de seneste 30 år, men Tamilsagen står stadig som en idealtypisk politisk skandale, hvor pressen er med til at afdække, at en minister og et ministerium ikke forvalter i overensstemmelse med lovgivningen. Sagen førte til, at den borgerlige regering under ledelse af Poul Schlüter trak sig i 1993, og at den ansvarlige justitsminister Erik Ninn-Hansen i 1995 blev idømt fire måneders betinget fængsel i en rigsretssag. Den er blevet kaldt den største nyere politiske skandale i Danmark og kan betragtes som den danske udgave af den amerikanske Watergate-skandale fra 1973 i dens betydning for både politik og undersøgende journalistik (se Ørsten i dette nummer). Dette blev illustreret i den seneste skandale af den type, hvor Birthe Rønn Hornbech i 2011 måtte gå af som integrationsminister, fordi statsløse havde fået uretmæssige afslag på dansk statsborgerskab. I dækningen af den sag blev der igen og igen draget paralleller til Tamilsagen i pressens dækning. ${ }^{4}$ 
Beslægtede skandaler handler om magtmisbrug og misbrug af offentlige penge til egen vinding. Et eksempel er bilagsskandalen, hvor den nuværende statsminister og daværende indenrigs- og sundhedsminister Lars Løkke Rasmussen, blev beskyldt for et overforbrug af offentlige penge. Tidligere har lignende sager ramt Arne Melchior og Ritt Bjerregaard, som begge måtte trække sig som ministre. Disse sager ligger i grænselandet mellem brud på de normer, som findes for personer i offentlige embeder, og reelle brud på den eksisterende lovgivning.

En sag, der rummede både ulovlig forvaltning og overforbrug af offentlige penge, er Brixtofte-sagen fra 2002 , hvor en af sagens spektakulære punkter var, at skatteborgerne havde betalt rødvin til 8.000 kroner flasken, men hvor der også var andre former for embedsmisbrug og mandatsvig. Sagen blev afsløret af avisen B.T. i en række artikler, der førte til, at sagens hovedperson, den daværende borgmester i Farum Kommune Peter Brixtofte, blev suspenderet og senere dømt to gang to års ubetinget fængsel, mens B.T.'s journalister vandt årets Cavlingpris for deres undersøgende journalistik i en sag, som både dækker et brud på offentlige normer, såsom et voldsomt forbrug på repræsentationskonti, og overtrædelser af lovgivningen.

I 2003 blev den daværende miljøminister Hans Christian Schmidt centrum for en skandale, fordi han havde overtrådt normerne for tildeling af midler fra en velfærdspulje. Han havde selv været med til at fordele penge til projekter i både sin egen hjemby og i hjembyerne for forligspartiernes miljøordførere. Det førte blandt andet til, at Finansministeriet lavede strammere retningslinjer for, hvordan sådanne puljer skal forvaltes. Denne skandale hører altså hjemme i kategorien for brud på normer $i$ en offentlig position. Disse typer skandaler er alle tæt knyttet til journalisternes rolle som samfundets vagthund, hvor pressen udgør en fjerde statsmagt, som skal overvåge, at der ikke foregår uretmæssige ting i de tre øvrige magtinstanser i magtens tredeling mellem den lovgivende, udøvende og den dømmende magt. Pressen kan naturligvis ikke overvåge alle handlinger hele tiden, og derfor tjener denne type skandaler en vigtigt - og måske først og fremmest afskrækkende - funktion i demokratiet (Graber 2003). Typisk for disse skandaler er også, at de samtidig ofte vil køre i det politiske system eller retssystemet, hvor undersøgelseskommissioner, eller som i tilfældet med Tamilsagen en rigsretssag, sikrer, at skandalerne får længerevarende opmærksomhed i pressen og offentligheden. Denne slags skandaler er en vigtig del af pressens funktion i et velfungerende demokrati, hvor politikerne holdes ansvarlige over for de borgere, de repræsenterer.

\section{Privatlivet}

Selvom de danske politiske journalister ikke ligger så langt fra deres britiske kolleger, når det gælder om vigtigheden af ,at give folk et indblik i politikernes privatliv“, er det et begrænset antal medierede skandaler, der omhandler normbrud i privatlivet. Herunder hører sexskandaler, som forekommer noget oftere i Storbritannien end i Danmark.

En af de få undtagelser var, da det unge medlem af kommunalbestyrelsen i Køge, Anders Møller, i 1997 blev

Tabel 2: Udvidet typologi med danske medierede politiske skandaler

\begin{tabular}{|c|c|c|c|}
\hline & Regelbrud/brud på lovgivning & Normbrud & $\begin{array}{l}\text { Practice as you preach (overskridelse } \\
\text { af grænsen mellem den private og of- } \\
\text { fentlige sfære) }\end{array}$ \\
\hline Det offentlige liv & $\begin{array}{l}\text { Brud på regler forankret i lovgivning i det } \\
\text { offentlige virke som politiker. } \\
\text { Eksempelvis Tamilsagen } \\
\text { Brixtoftesagen } \\
\text { Statsløse-sagen (Birthe Rønn Hornbech) }\end{array}$ & $\begin{array}{l}\text { Brud på normer i det offentlige virke som } \\
\text { politiker. } \\
\text { Eksempelvis Hans Christian Schmidts for- } \\
\text { skelsbehandling i tildeling af puljemidler }\end{array}$ & \multirow{2}{*}{$\begin{array}{l}\text { Private brud på normer/regler, som poli- } \\
\text { tikerne selv prædiker i deres offentlige virke } \\
\text { Eksempelvis Helle Thorning-Schmidts } \\
\text { skattesag } \\
\text { Henriette Kjærs (og især hendes mands) } \\
\text { rod i privatøkonomien } \\
\text { Jakob Bukstis overtrædelse af fartgrænsen }\end{array}$} \\
\hline Privatlivet & $\begin{array}{l}\text { Brud på regler forankret i lovgivning som } \\
\text { privatperson uden forbindelse til det offent- } \\
\text { lige virke som politiker } \\
\text { Eksempelvis Flemming Oppfeldts sexsag }\end{array}$ & $\begin{array}{l}\text { Brud på normer eller samfundsmoral som } \\
\text { privatperson uden forbindelse til det offent- } \\
\text { lige virke som politiker. } \\
\text { Eksempelvis Jeppe Kofods sexskandale } \\
\text { Anders Møllers lurerskandale }\end{array}$ & \\
\hline
\end{tabular}


afsløret i gennem et hul i en væg at lure på kvinder, der gik i solarium i Køge Svømmeland. Han måtte betale en bøde for blufærdighedskrænkelse og trække sig fra sin post som kulturudvalgsformand, en funktion, som paradoksalt nok betød, at han blandt andet var øverst ansvarlig for den svømmehal, hvor han fik påbud om ikke at vise sig. Sagen viste sig således at indeholde en reel lovovertrædelse og ikke blot et normbrud.

Valgbarhedsnævnet afgjorde dog, at han kunne fortsætte som politiker, men han måtte finde sig $\mathrm{i}$ at blive kaldt Køge-lureren eller Lurer-Anders i pressen. Og da han i 2002 som Folketingsmedlem blev indblandet i en sag, hvor han blev anklaget for sexchikane og med partiets mellemkomst indgik forlig med en sekretær, oplevede han en ny storm, og hans politiske karriere fik en foreløbig ende.

I 2004 skrev medierne også om en sexsag, da Venstres folketingsmedlem Flemming Oppfeldt blev anklaget og senere idømt fire måneders betinget fængsel for at have haft sex med en 13-årig dreng, men her var der også tale om en decideret lovovertrædelse, hvilket betyder, at den hører hjemme i en anden kategori end skandaler, der tager udgangspunkt i et brud på uformelle normer (se tabel 2).

En sag fra 2008, hvor Socialdemokraternes udenrigsordfører, Jeppe Kofod, blev afsløret i at have dyrket sex med en 15-årig pige i forbindelse med et kursus arrangeret af Dansk Socialdemokratisk Ungdom, illustrerer, hvordan balancen i sexsagerne er hårfin. Ekstra Bladet førte an med overskrifter som „Den liderlige socialdemokrat“ og „Pigen måtte tage fortrydelsespille: Jeppe brugte ikke gummi“. Jeppe Kofod havde dog ikke gjort sig skyldig $i$ en lovovertrædelse, men overtrådt en moralsk grænse samt et internt kodeks i Dansk Socialdemokratisk Ungdom. Den hårdhændede behandling fra både medierne og partiledelsen, som tilsyneladende pressede ham til at trække sig som ordfører, betød, at folkestemningen forholdsvis hurtig vendte til fordel for Kofod. Det resulterede i overskrifter som „Stop fordømmelsen“ (i Ekstra Bladet selv), „Stop hysteriet“ og „Rendyrket puritanisme“. Jeppe Kofod er i dag igen udenrigspolitisk ordfører for Socialdemokraterne, og sagen er blevet en parentes. Det tyder altså på, at danske journalister opfatter det at give folk et indblik i politikernes privatliv anderledes end deres britiske kolleger. Når man ser på rolleopfattelserne, er der betragtelig afstand mellem britiske og de danske journalisters opfattelse af, om det er vigtigt at levere underholdning og afslapning. Det kan være forklaringen på, at der optræder færre kulørte sexskandaler i de danske medier end i de britiske, at privatlivet i Danmark i højere grad end i Storbritannien hører privatlivet til.

\section{Mellem det offentlige og det private liv}

Det betyder dog ikke, at de danske politikeres privatliv udelukkende hører privatlivet til. I 2005 måtte Henriette Kjær trække sig som forbruger- og familieminister, da det blev afsløret, at hun var dømt som dårlig betaler. Dette førte til en politisk skandale ud fra argumentet om, at det var svært foreneligt med posten som forbrugerminister, selvom det var et rent privat anliggende. Altså var et brud på normer og lovgivning i forbindelse med økonomisk forbrug i privatlivet uforeneligt med at optræde i en offentlig rolle som forbrugerminister.

Det samme gjorde sig gældende, da Jacob Buksti i 2003 blev snuppet på en motorvej med en fart på 173 $\mathrm{km} / \mathrm{t}$, hvor man måtte køre 110. Dette blev anset for at være uforeneligt med hans hverv som næstformand for regeringens trafiksikkerhedskommission. Og da socialdemokraternes leder Helle Thorning-Schmidt og hendes mand i 2010 blev beskyldt for skattesnyd og -spekulation, var det også med det argument, at Socialdemokraternes politik er lagt an på, at de bredeste skuldre skal bære de tungeste byrder i kraft af deres skattebetalinger, men at Helle Thorning-Schmidt ikke selv levede op til det $\mathrm{i}$ sit private liv. Helle Thorning-Schmidt og partikollegaen Mette Frederiksen har været involveret i lignende - omend mindre - politiske skandaler, fordi de har valgt at have børn i privatskoler, mens de i deres offentlige hverv som politiker lægger stor vægt på den samfundsmæssige vigtighed af folkeskolen.

Denne type skandaler kan også kaldes en slags „practice as you preach"-skandaler (se tabel 2). Logikken er, at politikerne i privatlivet skal leve op til de ting, de prædiker i deres offentlige hverv (Thompson 2002: 28). Dette argument bliver fremført i diverse kommentarer og ledere i medierne, der berører rationalet bag skandalerne, og i en meningsmåling blandt et repræsentativt udsnit af danskerne fra i år viser, at 84 procent mener, at der skal være en sammenhæng mellem det en politiker siger, og hvad vedkommende gør i sit privatliv. ${ }^{5}$

Der er dog tilsyneladende grænser i forhold til at afsløre politikerne i privat at bryde de normer, som de prædiker offentligt. Da Ekstra Bladet i slutningen af 2010 gravede sig ned i miljøminister Karen Ellemanns skraldespand og afslørede eksempler på, at hun ikke i levede op til det, hun prædikede som minister i forhold til affaldssortering og madspild, blev afsløringen mødt af både fordømmelse og latterliggørelse og kom aldrig i nærheden af at blive til en skandale, der blev bredt samlet op af medierne. En meningsmåling blandt danskerne viste da også, at 68 procent af de adspurgte mente, at Ekstra Bladets gennemrodning af ministerens private skraldespand ikke var i orden, mens 29 procent fandt det i orden. ${ }^{6}$ 
Ligesom i Tyskland er antallet af skandaler, der involverer privatlivet, stigende i Danmark (se Ørsten i dette nummer). Samtidig er disse skandaler ligesom i Tyskland omstridte, og grænsen for, hvilke aspekter af privatlivet der skal rapporteres om, bliver løbende afprøvet og debatteret. Debatterne tyder på, at der stadig er en hårfin grænse mellem de dele af privatlivet, som er relevante, og de, som ikke er, selvom den tilsyneladende har rykket sig.

De medierede skandaler i Danmark relaterer sig altså stadig mest til politikernes offentlige rolle, selvom der er eksempler på, at både lovbrud og normbrud i den private sfære bliver til politiske skandaler. Det er dog i særlig grad problematisk for politikerne, hvis deres lovbrud eller normbrud i privatlivet strider mod det, de prædiker om emnet i offentligheden. Disse "practice as you preach“skandaler oplever man også i andre lande (Thompson 2002; Allern og Pollack 2009), og de konstituerer en kategori af skandaler, hvor der ikke er nogen klar grænse mellem det offentlige og private liv, og hvor der skal være overensstemmelse mellem de to.

\section{Den journalistiske kultur og politiske skandaler under forandring?}

Når Danmark sammenlignes med de tre øvrige lande, ligger den danske dækning af politiske skandaler tættest på den tyske med vægt på vagthundsrollen. I modsætning til i Spanien tyder intet på, at der er åben partiskhed. Alle medier følger op på de store sager, uanset hvilket politisk standpunkt de normalt vil søge at fremme i deres opinionsstof. Der er også en modvilje mod den britiske journalistiske kultur, hvor underholdningsrollen er afspejlet i dækningen af politikernes sexliv, og hvor der jævnligt anvendes etisk diskutable journalistiske metoder som skjult kamera eller betaling for en god historie. Det er ikke overraskende, at den danske dækning af politiske skandaler er tættest på den tyske. Begge lande er en del af det mediesystem, som Hallin og Mancini (2004) betegner som det demokratisk korporative. Storbritannien er derimod en del af det liberale mediesystem, hvor blandt andet en hård konkurrence på avismarkedet fremmer en anden journalistisk stil og kultur. Spanien er en del af det polariserede pluralistiske mediesystem, hvor journalisterne ikke i samme grad som i de andre mediesystemer har professionaliseret en vagthundsrolle, og hvor medierne mere åbent tager politisk parti. Disse forskelle på mediesystemerne og de journalistiske kulturer skinner altså tilsyneladende igennem, når det kommer til de medierede politiske skandaler.

Forskellene betyder dog ikke, at de danske politikeres privatliv slet ikke dækkes. Faktisk finder de danske politiske journalister det mere vigtigt at give folk indblik i politikernes privatliv end deres kolleger i Tyskland og
Spanien. En slags skandaler, som er forholdsvis hyppig i de danske medier, er, hvad vi har valgt at kalde "practice as you preach"-skandaler. I Danmark er politikernes privatliv blevet genstand for skandaler i tilfælde, hvor de har brudt normer, som deres politiske identitet eller politiske forslag bygger på, altså er det et spørgsmål om at udstille politikeres hykleri og stille dem personligt til ansvar (Thompson 2002; Allern \& Pollack 2009). Det vil sige, at normerne ikke er forankret i lovgivning og ofte ikke er en del af den generelle samfundsmoral, men er normer, som de lægger til grund for deres egne politiske holdninger, som det er tilfældet med socialdemokrater, der sender deres børn i privatskole i stedet for folkeskolen.

Omvendt går der i Danmark også en grænse i forhold til, hvordan journalisterne afslører sådanne skandaler, som det var tilfældet, da Ekstra Bladet gennemrodede Karen Ellemanns affald. Formiddagsaviserne har ind i mellem brudt de normer og roller, som definerer den danske journalistiske kultur, men indtil nu har det været sådan, at andre journalister og politiske modstandere sjældent følger op på den slags sager, og at offentligheden hurtig bliver synlig i fordømmelsen af journalistikken i den type sager, som det skete i sagen omkring Jeppe Kofod og Karen Ellemann. Det viser, at skandalerne i høj grad er et kulturelt fænomen, og at nationale særpræg forbliver vigtige trods ensartede strukturelle udviklinger på tværs af landene som kommercialisering, øget konkurrence på mediemarkedet og en 24-timers nyhedscyklus. Danske journalister vil i de fleste tilfælde lade en politiker, der er sin kone utro, være i fred, mens de vil gå kritisk til en politiker, der bruger skattepenge på dyr rødvin.

Det er klart, at den journalistiske kultur er indlejret $i$ en større national kultur, som journalisterne er en naturlig del af. Der er da også et stærkt overlap mellem den journalistiske kultur og den generelle nationale kultur, når det kommer til distinktionen mellem privat og offentlig moral. Den danske værdiundersøgelse har vist, at danskerne i sammenligning med andre europæere er mindre tilbøjelige til anse misbrug af sociale goder og skattesnyd, der går ud over fællesskabet, som acceptabelt. Omvendt er danskerne mere tolerante end europæerne generelt, når det kommer til private anliggender såsom skilsmisser eller „tilfældige seksuelle forhold“, som det formuleres i undersøgelsen (Gundelach 2004, 272).

Det er dog for tidligt at sige, om det bliver en trend i formiddagsaviser alligevel at fokusere på den slags politiske skandaler, fordi der er et publikum for det. Sker det, kan det have vigtige demokratiske konsekvenser. Godt nok havde historien om Jeppe Kofods sexliv eller historien om Karen Ellemanns skraldespand ikke i sig selv politiske konsekvenser for de to politikere. Konsekvenserne ved 
en tabloidpresse, som graver i folks privatliv eller skraldespande, vil snarere risikere at vise sig i det lange løb. Hvis ingen aspekter af privatlivet er hellige for pressen, vil potentielt gode kandidater måske tænke sig om to gange, inden de opstiller til et valg eller påtager sig en ministerstilling eller andre tillidshverv, hvilket naturligt vil være et tab for demokratiet.

\section{Litteratur}

Allern, S \& Pollack, E. (red.) 2009, Skandalenes markedsplass; Politik, moral og mediedrev, Fagbokforlaget, Bergen.

Canel, MJ \& Sanders, K 2006, Morality tales; political scandals and journalism in Britain and Spain in the 1990s, Hampton Press, Cresskill.

Deuze, M 2002, Journalists in the Netherlands; an analysis of the people, the issues and the (inter-)national environment, Aksant, Amsterdam.

Diez-Nicolás, J \& Semetko, HA 1995, 'La televisión y las elecciones de 1993', in A Muñoz-Alonso \& JI Rospir (red.), Communicación Politica, Editorial Universitas, Madrid.

Donsbach, W 2008, 'Journalists' Role Perception', in W Donsbach (red.), The international encyclopedia of communication, Blackwell Publishing.

Donsbach, W \& Patterson, TE 2004, 'Political news journalists; partisanship, professionalism, and political roles in five countries', in $\mathrm{F}$ Esser \& B Pfetsch (red.), Comparing political communication; theories, cases, and challenges, University Press, Cambridge.

Esser, F \& Hartung, U 2004, 'Nazis, pollution, and no sex; political scandals as a reflection of political culture in Germany', American behavioral scientist, 47(8), pp. 1040-71.

Graber, D 2003, 'The Media and Democracy: Beyond Myths and Stereotypes', Annual Review of Political Science, 6, pp. 139-160.

Gundelach, P (red.) 2004, Danskernes sarprag, Hans Reitzels Forlag, København.

Hallin, DC \& Mancini, P 2004, Comparing media systems. Three models of media and politics, Cambridge University Press, New York.

Hanitzsch, T 2007, 'Deconstructing journalism culture: towards a universal theory', Communication theory, 17, pp. 367-85.

Holtz-Bacha, C 2004, 'Germany: how the private life of politicians got into the media', Parliamentary affairs, 57(1), pp. 41-52.

Jiménez, F 2004, 'The politics of scandal in Spain. Morality play, social trust, and the battle for public opinion', American behavioral scientist, 47(8), pp. 1099-121.

Lloyd, J 2004, What the media are doing to our politics. Constable, London.

Lull, J \& Hinerman, S 1997, 'Media scandals', in J Lull \& S Hinerman (red.), Media scandals. Columbia University Press, New York.

Pujas, V 2002, 'Explaining the wave of scandal: the exposure of corruption in Italy, France and Spain', in R Kuhn \& E Neveu (red.), Political journalism; new challenges, new practices, Routledge, London.

Sanders, K \& Canel, MJ 2006, 'A scribbling tribe; reporting political scandal in Britain and Spain', Journalism, 7(4), pp. 453-76.
Schudson, M 2004, 'Note on scandal and the Watergate legacy', American behavioral scientist, 47(9), pp. 1231-38.

Skovsgaard, M, Albæk, E, Bro, P \& De Vreese, C under udgivelse, 'Media Professionals or Organizational Marionettes? Professional Values and Constraints of Danish Journalists', in DH Weaver \& L Willnat (red.) The Global Journalist.

Strömbäck, J \& Shehata, A, 2007, 'Structural biases in British and Swedish election news coverage', Journalism studies, 8(5), pp. 798812.

Thompson, JB 1997, 'Scandal and social theory', in J Lull \& S Hinerman (red.), Media scandals. Columbia University Press, New York.

Thompson, JB 2002, Den politiske skandale; magt og synlighed i mediealderen. Hans Reitzels Forlag, København.

Tumber, H 2004, 'Scandal and media in the United Kingdom; from Major to Blair', American behavioral scientist, 47(8), pp. 1122-37.

Tumber, H \& Waisbord, S 2004, 'Introduction: Political scandals and media across democracies, volume II', American behavioral scientist, 47(9), pp. 1143-52.

Van Aelst, P, Brants, K, Van Praag, P, De Vreese, CH, Nuytemans, M \& Van Dalen, A 2008, 'The fourth estate as superpower? An empirical study of perceptions of media power in Belgium and The Netherlands', Journalism studies, 9(4), pp. 494-511.

Van Dalen, A, Albæk, E \& De Vreese, C 2011, 'Suspicious Minds. Explaining political cynicism among political journalists in Europe', European Journal of Communication, 26(2), pp. 147-162.

Van Dalen, A \& Van Aelst, P under udgivelse, 'Political Journalists: Covering Politics in the Democratic Corporatist Media System', in DH Weaver \& L Willnat (red.) The Global Journalist.

Vos, TP 2009, 'Journalistic role conceptions: a bridge between the reporter and the press', Artikel præsenteret ved den årlige International Communication Association-konference.

Weaver, DH (red.) 1998, The global journalist: News people around the world. Hampton Press, Cresskill, NJ.

\section{Noter}

1 Kjærgaard, Jan (27. januar 2011). Jeg vil ikke være med i den sæbeopera. Ekstra Bladet.

2 Vi ønsker at takke de to anonyme reviewere, som er kommet konstruktiv kritik af en tidligere version af denne artikel. Samtidig vil vi gerne takke forskergruppen ved Center for Journalistik på Syddansk Universitet for konstruktiv kritik af en tidligere version af artiklen.

3 For at styrke den eksterne validitet har vi diskuteret udvalget og klassificeringen af skandaler med journalister og politologer i Danmark.

4 En søgning i databasen Infomedia på ordene „Birthe Rønn Hornbech“, „tamil*“ og „statsløse“ for perioden 1. januar 2011 til 21 . marts 2011 giver $i$ alt 372 hits.

5 Ellesøe, Anne Sofie, Jensen, Gitte Bank. (10. februar 2011). Opfør dig pænt, politiker - også i privatlivet 24 Timer.

6 Aagaard, Jens (26. december 2010). Ellemann fandt vindersag i skraldet. Søndagsavisen. 